\title{
The Effect of Supply Chain Management Practices on Operational Performances in Selected Wheat Flour Factories in Adama, Oromia Regional State, Ethiopia
}

\author{
BOGALE ALEMU REFU (PhD, PGD, MBA) \\ College of Business and Economics, Arsi University, Asella, Ethiopia \\ Musa Jemal (MA) \\ Department of Logistics and Supply Chain Management, Arsi University, Asella, Ethiopia
}

\begin{abstract}
The main purpose of this study was to investigate the effect of supply chain management practice and its effect on the operational performance of selected wheat flour factories in Adama city. Descriptive and explanatory research designs were used. The sample of the study was senior officers/executives in charge of SCM practice of the targeted factories who have rich experiences about the operation and management of supply chain practices in their respective factories. Those executives include general manager, production or technical manager, supply or purchasing manager, marketing manager, commercial manager, and inventory manager. The major data collection tools in this study were questionnaires and interviews. In the questionnaires, there are a set of questions included in each aspect of the SCM which were derived from extensive literature as well as the researcher's discussion with supply chain professionals. The collected data were analyzed using both descriptive statistics and inferential statistics. Accordingly, the major analysis of the findings indicates that the practice of the factories regarding their relationship with suppliers was focused on helping them to meet the factory's needs rather than building long term stable strategic partnership. In relation to the internal integration of the factories, the finding reveals that there is a strong internal operation within the factories.
\end{abstract}

Key terms: Supply Chain Management, Supply Chain Management Practice, Operational Performance, Wheat flour factories.

DOI: $10.7176 /$ IEL/10-3-02

Publication date: November $30^{\text {th }} 2020$

\section{INTRODUCTION}

In today's highly competitive global business environment, there is an increased focus on to create value and deliver it to their customers. Concurrent to the focus on customer value, the market place in which businesses operate today is widely recognized as being complex and turbulent. The fast introduction of new products with shorter life cycle, growing customer satisfaction and ongoing development of information and communication technologies (ICT) and transportation infrastructure have forced business to invest in and give direct attention to their supply chain (Christopher,2005).

A Supply chain (SC) consists of the whole activities associated with products and services movement from raw material stage to final products which are consumable by customers. This movement includes financial and information flow as well as material flow. In other words, supply chain is all about individual, is a network consisting of downstream and upstream organizations which are involved in different processes and activities that create value for end customers in the form of products and services (Christopher, 1998).

SCM is the task of integrating organizational units along a supply chain and coordinating material, information and financial flows in order to fulfill (ultimate) customer demands with the aim of improving the competitiveness of a supply chain as a whole (Stadtler, 2008). Therefore, supply chain management practices play decisive roles in competitive positioning and new sources of business competition that lie outside the walls of the company; SCM determined by how effectively firms link their internal operations with their supply chain partners such as suppliers, distributors, wholesalers, retailers and end customers (Burt et al., 2002).

Effective supply chain management (SCM) has become a potentially valuable way of securing competitive advantage and improving organizational performance since competition is no longer between organizations, but among supply chains ( $\mathrm{Li}$ et al., 2006). Therefore, organizations have begun to realize that it is not enough to improve efficiencies within an organization, but their whole supply chain has to be made competitive.

Ethiopia is the origin for the production of wheat in the world. Some parts of the country like Arsi-Bale region is well known for the production of high quality wheat. As a result, Ethiopian manufacturing is mainly dominated by food production, especially in wheat flour sector (UNIDO, 2009).

The wheat flour industry in Ethiopia is currently growing investment and the demand for the product is increasing highly and as a result there are new entrant of investors to this investment sector and the existing ones are also engaged in the expansion of the production to further food complexes such as production of biscuit, 
macaroni and spaghetti parallel with the production of the flour. Wheat flour is both industrial as well as consumer goods. Increased application of wheat flour for industrially processing of food products such as spaghetti and macaroni would also have great bearing of future wheat flour demand. It is also applied for bread making, cakes and biscuits and porridge at household level. (Sutton and Kellow, 2010).

Agricultural resources that are the base for biscuit, spaghetti and macaroni manufacturing are available in fairly large quantities, being the main source of comparative advantages of the sector. However, actual utilization of the sector largely depends on the ability to operate efficiently and the ways industries are managed. It is generally believed that resources in the flour manufacturing industries are being utilized inefficiently. Thus, managing the Supply Chain practice in this flour factories have a major impact on the performance of all parties involved in the chain and the production of wheat flour for industrially processing food products and for consumer's consumption. Therefore, this research is made to investigate the practical supply chain management practices and its effect on the factories operational performances of wheat flour producing factories in Adama city, Oromia regional State, Ethiopia.

\section{REVIEW OF RELATED LETRATURES}

\subsection{An Overview of Supply Chain}

Organizations are facing different kinds of challenges in their effort of competing in today's dynamic global markets. Many organizations continue to struggle to understand the complex issues associated with the coordinated planning and supply chain activities among the members of their supply networks (Palmer, 2012).(Cox, 20011) defines supply chain as a formation of a value chain network consisting of individual functional entities committed to provide resources and information to perform its operation in the most efficient way. These functional entities include procurement, production, inventory management, supplier management and efficient flow of information among the customers that cut across functions in the organization (Arnold and Chapman, 2004).

A supply chain consists of two or more legally separated organizations, being linked by material, information and financial flows. These organizations may be firms producing parts, components and end products, logistic service providers and even the (ultimate) customer himself (Stadtler, 2008). On the other words (Wadhwa and Saxena, 2007) also describe supply chain as important aspect of business strategy that require integrated decision making and includes the entities from the origin point to the final consumption such as suppliers, customers and the organization itself. The pace of change and the uncertainty about how markets will evolve has made it increasingly important for companies to be aware of the supply chains they participate in and to understand the roles they play.

Collaboration is necessary among other organization for effectiveness in terms of time, cost and performance (Bower sox et al., 2010).Each organization focuses on a particular area of competence and then depends on other partners in achieving other parts of the process. These interdependence among organization in supply chain has enhances the pro-activeness and responsiveness to customers 'needs and great reduction in time to bring new products and services to the market in order to meet the continuous change in the demand of customers.

This leads to increase in creativity in the system and also changes business dynamics and priority often (Wadhwa \& Saxena, 2007; Bowers ox et al.,2010).organizations now focus on the arrangement and rearrangement of supply chain processes and activities to create further opportunities in terms of cost reduction, market responsiveness, facilities utilization and human resource optimum utilization (Christopher, 2005). Clearly, there is much to be gained by managing the supply chain network to improve organizational performance and efficiency (Collins, 2003).

\subsection{Objective of SCM}

The basic objective of supply chain management is to optimize performance of the chain to add as much value as possible for the least cost possible. In other words, it aims to link all the supply chain agents to jointly cooperate within the firm as a way to maximize productivity in the supply chain and deliver the most benefits to all related parties (Finch,2006).The objective governing all endeavors within a supply chain is to increase competitiveness. This is because no single organizational unit now is solely responsible for the competitiveness of its products and services in the eyes of the ultimate customer, but the supply chain as a whole (Stadtler, 2008).

The dual focus of Supply Chain Management is on the application of models to increase the efficiency of organizations by improving the performance of an individual organization as well as that of the entire supply chain. Additionally the supply chain management reduces organization total cost ( $\mathrm{Li}$ et al, 2006). The main reason and objective of SCM is to provide a strategic weapon to build up and enhance sustainable competitive advantage by cost reduction without compromising customer satisfaction (Mentzer, et. al,2001).

\subsection{Supply Chain Management Practices}

Supply chain management practices have been defined as a set of activities undertaken in an organization to promote effective management of its supply chains that leads to value creation to end customer (Li et al. 
2006).Many manufacturers and distributors are working up to the potential for the major cost reduction and service improvements offered by implementing best practices in their supply chain. Supply Chain Management is now recognized as a critical business process for companies manufacturing or distributing products. This is because customers' demand for most products are ever more demanding in response time, in choice and in seeking more competitive prices and customers can choose from an increased number of suppliers (Lazarovic et al.,2007). Several studies have examined SCM practices which involve various dimensions. For example, Chow et al., (2008) suggest that supply chain features, integration, and customer services are typical of SCM practices. Chen et al., (2004) viewed SCM practices rather loosely as a set of practices consisting of customer channel, supplier channel, material flows, information technology and corporate culture. Sohal et al. (2001) considered five aspects of SCM, which are: Supplier and Customer Relationship, Information Sharing, Internal Operation, Information Technology and Supply Chain performance. Li et al., (2006) propose that for an effective SCM the firm should consider the following practices: strategic supplier partnership, customer relationship, level of information sharing, quality of information sharing, and postponement.

This study considered four of them as the basic supply chain practices from Sohal et al. (2001), which are: Supplier and Customer Relationship, Information Sharing, Internal integration and information Technology.

\subsection{Wheat Flour Industries in Ethiopia}

According to Food and Agriculture Organization 2017, Ethiopia is an agrarian country with more than $80 \%$ of its population living in the rural area. In recognition to the national food insecurity problem, the Government has given priority to food security and improvement of productivity. Yet nowadays, due attention is also given to value addition of agricultural products with the continuous economic growth. The private manufacturing sectors are attracting to agro industry manufacturing in order to meet the demand of the society for the food product. This can contribute to solve the issue of food insecurity, as stable economic growth and on other hand can create new job opportunities and revenue can be re-invested to solve the existing food insecurity problem in sustainable manner.

The type of wheat can be classified into hard, soft and medium type. As a result, in a sample there could be very soft wheat as well as hard wheat and the average value may tend to be hard or soft. Wheat factories are demanding these categories since it will determine the purpose it will be used at the end. The soft wheat will be used solely for wheat flour production while the harder wheat used to produce macaroni and spaghetti. In such cases there is price difference paid for wheat and such initiative need to be strengthen to improve the quality of the final product. Little effort is there in terms of targeting the wheat research and development towards the quality requirement as there is already food gap that has to be filled. The processing companies usually mix different quality wheat to attain a certain standards of the final product (Habtamu, 2010).

\subsection{SCM Practices of Wheat Flour Factories}

In wheat flour industry's strengthening the downstream actors and their business to business relationships will maximize market opportunities and provide market intelligence to the more upstream actors or customers. To access a market, the supplier sector needs to guarantee a quality supply of wheat for the factories (Tadesse Kenea Amentae, et al., 2017).

In order to obtain the right quantities and qualities of wheat, it requires investing in the upstream supply, with not only market intelligence, but also with specific services. These services can be technical, financial and organizational and will be increasingly supplied embedded in business transaction by private service providers or own staff. In wheat production, the issue of quantity and quality wheat production is emphasized and in order to overcome such problems lists of options could be identified.

In this the major target is to produce quality marketable surplus that could feed the increasing demand for wheat for industrial processing. Some of the bigger options could be giving Support for the existing commercial farmers to improve productivity, identifying the possibility of irrigated wheat production and improving the productivity of small scale farmers.

\subsection{Empirical Evidences on SCM Practices}

The issue of SCM practice is not obtain proper focuses by most researchers particularly Ethiopia. As far as the researcher's knowledge is concerned, there is no study that made an investigation specifically on wheat flour factories. However, the researcher comes across five recently carried out researches related to SCM practices on different manufacturing sector in Ethiopia.

Those are;

1. Impact of supply chain management practices on competitive positioning of Ethiopian Textile firms (Admaw, 2010)

2. Study on supply chain management practices of Kality food share company (Assefa, 2011)

3. Supply Chain Performance of selected leather Footwear firms in Addis Ababa (Hailemickael, 2011)

4. The effect of supply chain integration on operational performance and associated challenges a study on chemical 
and chemical product manufacturing firms in Ethiopia (Daniel, 2013)

5. Integrating Developing Country Manufacturing Industries into Global Supply Chain (Bete Georgise et al., 2014 Table 1: Summary of Empirical Evidences on SCM

\begin{tabular}{|c|c|c|c|}
\hline No & Title and Author & Objective of the study & Major findings \\
\hline 1 & $\begin{array}{l}\text { Impact of supply chain } \\
\text { management practices on } \\
\text { competitive positioning of } \\
\text { Ethiopian Textile firms } \\
\text { (Admaw, 2010) }\end{array}$ & $\begin{array}{l}\text { To create awareness about the concept, } \\
\text { principle and practices of supply chain } \\
\text { management in Ethiopian textile firms so } \\
\text { as to make them more competitive in the } \\
\text { global textile marketplace }\end{array}$ & $\begin{array}{l}\text { Supply chain management } \\
\text { practices in Ethiopian textile } \\
\text { firms are weekend the firms } \\
\text { do not use SCM as } \\
\text { competitive weapon. }\end{array}$ \\
\hline 2 & $\begin{array}{l}\text { Study on supply chain } \\
\text { management practices of } \\
\text { Kality food share company } \\
\text { (Assefa, 2011) }\end{array}$ & $\begin{array}{l}\text { To study the practices of supply chain } \\
\text { management from the five SCM } \\
\text { practices perspectives i.e. Supplier and } \\
\text { customer relationship, internal } \\
\text { operations, information sharing, } \\
\text { information technology and training and } \\
\text { to see the integrations among SC partners }\end{array}$ & $\begin{array}{l}\text { Most SCM practices are } \\
\text { moderately practiced with in } \\
\text { the KFSC's SC }\end{array}$ \\
\hline 3 & $\begin{array}{l}\text { Supply Chain Performance } \\
\text { of selected leather Footwear } \\
\text { firms in Addis Ababa } \\
\text { (Hailemickael, 2011) }\end{array}$ & $\begin{array}{l}\text { To explore the extent to which selected } \\
\text { Medium and Large Size leather footwear } \\
\text { manufacturing firms in Addis Ababa } \\
\text { performs in those SCM variables and to } \\
\text { compare the mean performance } \\
\text { difference among firms in implementing } \\
\text { those SCM variables. }\end{array}$ & $\begin{array}{l}\text { There was significance } \\
\text { performance differences of } \\
\text { SCM among these Medium } \\
\text { and Large footwear firms } \\
\text { selected for the study }\end{array}$ \\
\hline 4 & $\begin{array}{l}\text { The effect of supply chain } \\
\text { integration on operational } \\
\text { performance and associated } \\
\text { challenges a study on } \\
\text { chemical and chemical } \\
\text { product manufacturing } \\
\text { firmsin Ethiopia (Daniel, } \\
2013 \text { ) }\end{array}$ & $\begin{array}{l}\text { To empirically examine the effect of } \\
\text { supply chain integration on } \\
\text { organizational performance and to } \\
\text { identify the associated challenges that } \\
\text { affect firms supply chain integration }\end{array}$ & $\begin{array}{l}\text { Significant positive } \\
\text { relationship between supply } \\
\text { chain integration construct } \\
\text { and operational performance } \\
\text { of firms }\end{array}$ \\
\hline 5 & $\begin{array}{lr}\text { Integrating } & \text { Developing } \\
\text { Country } & \text { Manufacturing } \\
\text { Industries into Global } \\
\text { Supply } & \text { Chain } \\
\text { (BeteGeorgise et al., 2014) }\end{array}$ & $\begin{array}{l}\text { To examine the level of inter - } \\
\text { organizational and intra-organizational } \\
\text { supply chain integration practices in } \\
\text { developing country, Ethiopia. }\end{array}$ & $\begin{array}{l}\text { Low level of supply chain } \\
\text { relationship both in intra and } \\
\text { inter-organizational supply } \\
\text { chain integration level among } \\
\text { members }\end{array}$ \\
\hline
\end{tabular}

Source: Compiled by the researcher from empirical evidences.

\subsection{Conceptual Framework of the Study}

Conceptual framework of SCM practice and its effect on the operational performance of selected wheat flour factories is defined according to combination of analyzing theoretical findings of different researchers. Consequently, the SCM practices that are selecting in this study will be classified into four dimensions. These are strategic suppliers and customers' relationship, internal integration, information sharing and application of information technology. These four SCM practices can cover upstream (supplier partnership), downstream (customer relationship), internal integration and information sharing and ICT that coordinates both focal firms, and upstream and downstream supply chains. 


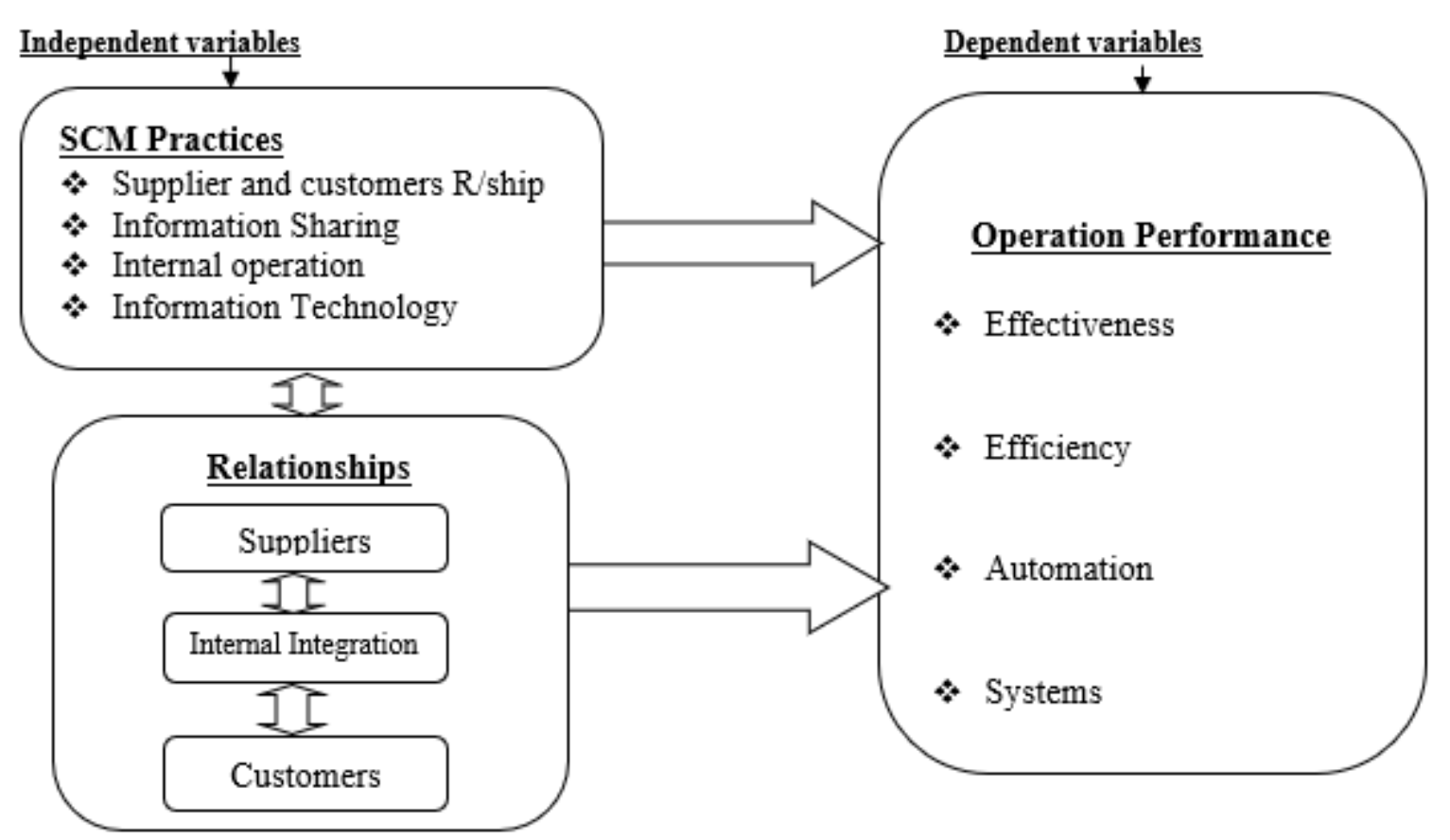

Figure 1: Conceptual framework of SCM practice

Source: Compiles by the researcher from different literature

\section{Significance of the Study}

The ultimate goal of any business establishment is to remain in business profitability through the production and sale of products or services. Without optimal profit, a business /firm cannot survive. One of the core activities in a business company is having a well - developed supply chain management practices. The ultimate success or failure of a company depends on its supply chain management systems.

The significance of this study lies in serving the following purposes:

It helps the given manufacturing sector to know the real practice of the supply chain management and to what extent it influences the operational performance of the selected wheat flour factories found in Adama city.

It enables the firms in the sector to understand the current practices of the SCM and to apply the supply chain management practices effectively in order to increase their operational performance to meet the high demand of the society for the wheat flour product and to make their company competitively advantageous through effective and efficient utilization of the resource in the sector.

The study is helpful to enhance the level of understanding of supply chain management in members of the manufacturing sector in Ethiopia. It serves as additional sources of information and gives green-light for academicians to further research on related areas.

\section{Statement of the Problem}

Companies significantly can improve their customer service and operational performances by recognizing the opportunities that exist in the supply chain management that develop a competitive supply chain based on speed, flexibility, innovation, quality and responsiveness (Thatte, 2007). Therefore, the primary goal of supply chain management is to enhance competitive performance by closely integrating the internal functions within a company and closely linking them with external operations of suppliers, customers, and other channel members (Kim, 2006).

The food supply chain needs effective management, integration, knowledge, and due attention throughout the supply chain. If properly implemented SCM can improve the company's responsiveness, flexibility and production efficiency (Makweba and $\mathrm{Xu}, 2009$ ). Even though, the supply chain management practice of manufacturing industries in Ethiopia is at its infancy stage of doing things and production procedures; the existing high market competition forces the firms to discover modern methods that will enable them to perform high and become competitive advantageous than their competitors. That is through their effective supply chain management.

The objective of this study is to investigate the SCM practice of the wheat flour factories and its effect on their operational performance in Adama City, Oromia Regional State, Ethiopia. As long as the researcher's knowledge is concerned, there is no study done on any manufacturing sector on SCM practices in Adama City. Since the flour manufacturing sector is the dominant one in the city, making the study on this specific sector can let to know the existing SCM practice. Not only that but also the study opened up the door to know the information 
sharing and application of ICT practices in this specific manufacturing industry particularly to supply chain management practices. As to the knowledge of the researcher, there are few studies that have been conducted on supply chain management which assesses the practice in different manufacturing sub-sectors of Ethiopian manufacturing industries. Among the studies done so far, Daniel (2013) SCM practice on chemical and chemical product manufacturing firms in Ethiopia, Assefa (2011) on SCM practice of Kality food complex, Hailemickael (2011) on Supply Chain Performance of selected leather Footwear firms in Addis Ababa and Admaw (2010) Impact of supply chain management practices on the competitive positioning of Ethiopian Textile firms.

Therefore, the researcher is interested to conduct this study on the SCM practice of the wheat flour factories and its effect on their operational performance in Adama City to fill the research gap in the area of the study at hand.

\section{Basic Research Questions}

In this study the researcher is attempted to answer the following basic research questions:

1. What are the practices of supply chain management in terms of supplier and customer relationship, information sharing, internal integration, and information technology of selected wheat flour factories in Adama city?

2. What is the overall effect of supply chain management practices on the operation performances of the wheat flour factories in Adama City?

\section{Objectives of the Study}

\subsection{General Objective}

The general objective of this study is to investigate the supply chain management practice of wheat flour factories and its effect on the operational performance of the factories found in Adama City, Oromia Regional State, Ethiopia.

\subsection{Specific Objective}

In addition to its general objective, the study had the following specific objectives:

1. To assess the existing practices of supply chain management in terms of supplier and customer relationship, information sharing, internal integration, and information technology perspectives in the wheat flour factories found in Adama City.

2. To explore the overall effects of supply chain management practices on the operational performance of wheat flour factories found in Adama City.

\section{RESEARCH DESIGN AND METHODOLOGY}

\subsection{Research Design}

A study design is an important part of research because it serves as a guideline as to how to carry out the study. Since the purpose of this study is to investigate SCM practices and their effect on the operational performance of wheat flour factories; both descriptive and explanatory research designs were used. More appropriate and selected to figure out what exists at present by determining the nature and existing practice of the issue in the study area. In this regard, as stated by (Cohen et.al 2007), descriptive research was used to describe the current situation of the topic under study. By its very nature, descriptive research answers who, what, where, when and how questions. The major purpose of descriptive research is describing the state of affairs as it exists. It helps to describe the situations of the issue under study quantitatively and qualitatively using the data collected through questionnaires and interviews.

Furthermore, (Kothari 2004) stated that explanatory technique is used and appropriate when the researcher has a single, metric criterion variable; which is supposed to be a function of other explanatory variables. The main objective of using this technique is to predict the variability of the dependent variable based on its covariance with all the independent variables. One can predict the level of the dependent phenomenon through regression analysis, given the levels of independent variables.

\subsection{Sample Size and Sampling Technique}

The sample of the study was senior officers/executives in charge of SCM practice of the targeted factories who have experience in the operation and management of supply chain practices in their respective factories. Thus, those executives include general manager, production or technical manager, supply or purchasing manager, marketing manager, commercial manager, and inventory manager were selected through a purposive sampling technique. The researcher selected those respondents based on their long time experiences in the area of the study at hands and they have enough knowledge to comprehend and respond to questions concerning the operational performance and SCM practices in their respective factories and included all of them to respond to the questionnaire. Thus, this sampling technique was used considering respondents' job position and their responsibilities directly related to supplying chain management's practices in the wheat flour factories and their 
number is small. Accordingly, the researcher selected 68 sample respondents who have a direct relationship with the issue being studied from the top officials of four factories as it has been indicated earlier.

\subsection{Nature and Sources of Data}

In this study, both primary and secondary sources of data were used. The primary source of data was collected from general manager, production or technical manager, supply or purchasing manager, marketing manager, commercial manager and inventory manager of 4 flour factories found in Adama City. The secondary data were collected from official documents of the selected factories and government offices related to supply chain management practices. Accordingly, both qualitative and quantitative data were used to get relevant and appropriate information on the specific issues of the study.

\subsection{Data Collection Tools}

The major data collection tools used in this study was questionnaires and interview. In the questionnaires, a set of questions on each aspect of the SCM derived from extensive literature as well as the researcher's discussion with Supply Chain professionals was included. The questionnaire consists of three sets of questions; the first section contains demographic questions such as work experience and job position of respondents in their organization. The second section elicits the practices of SCM with respect to suppliers and customer relationships, internal integration, information sharing, and information technology. The third part includes questions related to the operational performance of the factories. Accordingly, the respondents were asked to answer all of the questions using a Likert scale ranging from 1 to 5 (1= Very Low and 5= Very High).

\subsection{Method of Data Analysis}

In this study, the analysis of data was done using both descriptive statistics and inferential statistics using Statistical Package for Social Science (SPSS) version 26. For the analysis of demographic characteristics of the respondents' frequency and the percentage was used. With regards to items of SCM practices and operation performances, the results of descriptive statistics were used in analyzing the data. In addition, the correlation coefficient was calculated to see the relationship between SCM practices and the operational performance of the factories. Furthermore, multiple regression analysis was done to analyze the effect of SCM practices on the operational performances of the factories. Moreover, the regression analysis was used to identify the extent of influences of each variable of SCM practices on operation performances.

\subsection{Validity and Reliability of the Data Collection Tools}

According to (Cohen et.al 2007), the validity of a measurement instrument is about the extent to which the instrument measures what it is actually intended to measure. Whereas reliability of measurement instrument is referred to as the extent to which the instrument yields consistent result when the characteristics being measured has not changed. In order to assure data quality, the questionnaires prepared for this study were validated and tested at a pilot level for its reliability before distributing for sample respondents and used as a data collection tool. Primarily, the validity of the instruments was tested by two experts of the department including the research advisor to judge the items on their appropriateness and clarity of the contents.

\section{DATA PRESENTATION, ANALYSIS, AND INTERPRETATION}

\subsection{The Practices of Supply Chain Management}

Out of 68 questionnaires distributed to the respondents, $59(86.8 \%)$ were correctly filled and returned. Thus, data presentation and analysis in this study was based on the responses of 59 respondents from the targeted factories. In addition, interview responses obtained from eight general managers of the factories were also used in data presentation and analysis. The data collected for this study were organized and presented in tables. Subsequently, analysis and interpretation of the data were made. In addition, discussions on the findings of the study were made by comparing the results with the literature review and empirical evidence. This part focuses on the intensity of wheat flour manufacturing factories towards supply chain management practice. It focused on respondents' responses related to the first basic research question: What are the practices of supply chain management in terms of Supplier and Customer Relationship, Information Sharing, Internal Operation and Information Technology of wheat flour factories found in Adama city. The data related to each of the supply chain management practices are presented and analyzed separately as follows. 
Table 7.1: Suppliers and Customers Relationship

$$
\mathrm{N} / \mathrm{S} \quad \text { Item }
$$

1 Our Organization has built long term strategic partnership with suppliers

We regularly solve problems jointly with our suppliers

Our major supplier shares their production schedule with us

We help our major supplier to improve their process to better meet our needs

We have long-term relationship with our customers

6 There is a close involvement of our major customers in deciding upon issues such as customers relationship management

7 We frequently measure customers satisfaction

8 Our customers give us feedback on our product quality and delivery performances

All Items

\begin{tabular}{ccl}
$\mathrm{N}$ & Mean & \multicolumn{1}{c}{$\mathrm{SD}$} \\
59 & 3.07 & .962 \\
59 & 3.00 & 1.050 \\
59 & 2.80 & 0.826 \\
59 & 3.14 & 1.025 \\
59 & 3.08 & .988 \\
59 & 2.85 & 0.738 \\
& & \\
59 & 2.81 & .730 \\
59 & 3.36 & .996 \\
& & \\
59 & 3.014 & 0.823
\end{tabular}

Source: Researcher's survey

Concerning suppliers and customers relationship with the firms in SCM practices, Lambert and Cooper (2000), Sohal et.al (2001), stated that ideally, in a typical SCM structure, suppliers and customers brought together in one concurrent business process that spans the entire chain from initial source to the ultimate consumer. Furthermore, as argued by Li et.al (2006), the major purpose of every SCM is to minimize system-wide costs while satisfying customer service level requirements. Indeed, it is a customer-oriented process for integrating business planning and balancing supply and demand across the entire supply chain system.

Considering the above facts respondents were asked to rate the current SCM practice and their responses were organized and presented in table 7.1. Thus, the data in the table illustrated the respondents' responses on the extent of the relationship that exists between suppliers, customers and the case factories on eight items.

Regarding relation with suppliers, the data on the table shows that the factory's support to suppliers in order to improve their process to meet their needs tend to be the highest result $(M=3.14, S D=1.025)$. The results of the other two items results relating with the suppliers depict below moderate results; in that, the practices of the factories relating with the factories long term strategic partnership with suppliers $(\mathrm{M}=3.07, \mathrm{DS}=0.962)$ and solving problems jointly with them $(\mathrm{M}=3.00, \mathrm{M}=1.050)$ resulted below moderate levels. However, SCM practices of the factories regarding sharing of the production schedule with suppliers were found at a lower level $(\mathrm{M}=2.80$ $\mathrm{SD}=0.826$ ) than all other items. These imply the practice of the factories regarding the relationship with suppliers was somewhat focused on helping them to meet the factory's needs rather than building long term stable strategic partnerships, sharing their production schedule and jointly solving problems.

In fact, the findings indicate that suppliers and the company have adopted good relations in order to meet the companies' requirements. Moreover, as per the interview responses of general managers, concerning the assistance they make for major suppliers the majority of the interviewees said that in order to get a good quality of wheat from the suppliers they tend to support them by giving them money in advance and rarely transportation facilities. Concerning customer relationship with firms, that comprises activities like managing customer complaints, building long-term relationships with customers and improving customer satisfaction the data of the table shows that from the four items, receiving feedback from customers' on product quality and delivery performances was practiced higher than the remaining three items $(\mathrm{M}=3.36, \mathrm{SD}=0.996)$. Next to this measuring and evaluating customer satisfaction was almost highly practiced by the factories $(\mathrm{M}=3.85, \mathrm{SD}=0.638)$.

However, the practice of having long term relationships with the customer was found at a moderate level $(\mathrm{M}=3.08, \mathrm{~S} . \mathrm{D}=.988)$. The least practiced item, with a 2.85 mean score $(\mathrm{S} . \mathrm{D}=0.738)$ was about the involvement of major customers in deciding upon major issues of SCM, such as transportation, production, distribution and inventory management. In general, the overall mean results for items listed in table $4.1(\mathrm{M}=3.014, \mathrm{SD}=0.823)$ indicate a moderate level of factory practices concerning their relationship with suppliers and customers. Thus, it is important to consider what was stated by Chang et.al (2006), in that, building a long-term relationship with suppliers and customers helps to improve the flexibility of the supply chain by creating a mutual understanding among the members. 
Table 7.2. Internal Operation Practices

$\mathrm{N} / \mathrm{S}$

In our firm there is a real-time integration among all internal functions from procurement up to sales

2 In our firm there is a joint decision making with internal departments on the issues of inventory management

Employees in the company consider that departments are in harmony with each other

4 Customers believe that Service improvement is high

5 Marketing department consults operation department before accepting special feature requests Marketing and distribution departments consults operation departments before accepting early delivery requests

7 Periodic interdepartmental meetings among internal functions are commonly utilized

8 There is little/no conflict between departments All Items

Source: researcher's survey

Internal operations are the basis for developing a competitive advantage before embarking into the external partners such as suppliers and customers. As stated by Narasimhan et.al, (2004), in order to effectively operate the production process and to achieve high customer's satisfaction, full system visibility within an organization from the point of purchasing through distribution is essential. Poor internal operations can cause failure in production efficiency and relationship with external partners. The data in the table 7.2 illustrates respondents responses on eight variables that were used to see the extent of internal integration of the case factories in terms of real-time integration, joint decision making, employees perception of company's goals with respect to their department, extent of continuous and instantaneous product and service improvement and consultation and discussion practices during decision making internally, and extent of conflict between departments related to the practice of supply chain management in the factories. Thus, the overall mean value of the respondents $(\mathrm{M}=3.074, \mathrm{SD}=1.067)$ reveals that there is good internal operation within the factories in which most of the mean results convey above average results. The highest mean value was identified with the practice of consultation between marketing, operation and distribution departments; in that the practice of consultation between marketing and distribution department $(\mathrm{M}=3.34 \mathrm{SD}=1.108)$ was a little higher than between marketing and operation departments $(\mathrm{M}=3.34, \mathrm{SD}=1.064)$. Similarly, concerning the practice of a real- time integration among all internal functions from procurement up to sales $(\mathrm{M}=3.15, \mathrm{SD}=0.997$ and joint decision making with internal departments on the issues of procurement, inventory management, production and distribution $(\mathrm{M}=3.07, \mathrm{SD}=1.108)$ were identified above overall mean result of the table. On the other hand, the last two items, which is the extent of conflict between departments related to the practice of supply chain management of the factory $(\mathrm{M}=3.00, \mathrm{SD}=1.145)$ and commonly practicing periodic inter departmental meetings among internal functions of the factory $(\mathrm{M}=2.86, \mathrm{SD}=1.074)$ are relatively the lowest mean value which is out of other items listed in the table used to see the extent of internal operation practices of SCM in the factories.

Since, internal operation is the most critical factor to measure factory's internal efficiency and the potential to go for external integration; it is expected to be higher and stronger. Thus, companies should be internally efficient and effective before embarking on external integration (Lazarevic et. al, 2007). However, the results of this study regarding internal operation practice of flour factories were found at moderate level.

Table 7.3. Information Sharing Practices

\begin{tabular}{|c|c|c|c|c|}
\hline $\mathrm{N} / \mathrm{S}$ & Items & $\mathrm{N}$ & Mean & SD \\
\hline 1 & $\begin{array}{l}\text { There is effective information sharing with our customers on sales forecast new } \\
\text { product development }\end{array}$ & 59 & 2.53 & 0.728 \\
\hline 2 & $\begin{array}{l}\text { There is effective information sharing with our suppliers on sales forecast new } \\
\text { product development }\end{array}$ & 59 & 2.41 & 0.8 \\
\hline 3 & Our firm has adequate ability to share standardized & 59 & 2.47 & \\
\hline 4 & Our firm has adequate ability to share customized information internally & 59 & 2.47 & \\
\hline 5 & $\begin{array}{l}\text { Our firm maintains an integrated database method to facilitate information sharing } \\
\text { within internal dept. }\end{array}$ & 59 & 3.18 & \\
\hline & All Items & 59 & 2.612 & \\
\hline
\end{tabular}

Source: researcher's survey

Information sharing is the backbone of supply chain management practice that lets the supply chain partners exchange information regularly and able to work together as a single entity (Stadtler et. al, 2008). As a result, the factories can understand and fulfill the needs of the end customer better and hence can respond quickly to changing 
the market (Li et. al, 2006).

Considering the above facts, in this study five items related to information sharing practices were used for the respondents to rate the existing information-sharing practice status of their factories. The variables indicate the extent of firms' information-sharing practices in terms of sales forecast and new product development with customers and suppliers, sharing standardized and customized information internally, maintaining an integrated database between departments and effectively sharing of production information internally.

Accordingly, the data in table 7.3 shows, the mean value of each item and overall mean that can indicate the information-sharing practice of the case factories internally and with its suppliers and customers. The overall mean score of the table $(\mathrm{M}=2.612 \mathrm{SD}=0.813$ depicted that the information-sharing practice of the case factories was found below a moderate level, indicating insufficient information-sharing practice with its suppliers, customers and internally within the organization.

According to the data of the table, effective information sharing on sales forecasts and new product development with customers and suppliers scored $2.53(\mathrm{SD}=0.728)$ and $2.41(\mathrm{SD}=0.853)$ means respectively.

Furthermore, maintaining an integrated database and access method to facilitate information sharing between departments $(\mathrm{M}=2.47, \mathrm{SD}=0.815)$ and adequately sharing of standardizing and customized information internally $(\mathrm{M}=2.47, \mathrm{SD}=0.858)$ also indicted insufficient information-sharing practice of the factories internally. However, the practice of sharing production information between departments related to SCM scored moderate results $(\mathrm{M}=3.18, \mathrm{SD}=0.833)$.

Besides, the information obtained from interview results shows that most of the factories have the trend of making decisions on sales forecasts and new product development without sharing information externally as well as internally. According to the response of these interviewees, they did it because in most of the factories they have no such close intimacy and strategic partnership with suppliers and customers and the suppliers as well as customers had no roll in the information shared about sales forecasts and new products development. In addition, the management of the companies assumed that not sharing information sufficiently with suppliers and customers externally and among internal departments, considered as a competitive advantage to control the market share.

Moreover, the actual practices observed in the factories showed, almost in all of them most of the information was controlled and managed by the owner or the general manager and without the permission of the owner any information is not shared for others even for the departments directly linked with the SCM of the factories.

In general, all the above data confirmed that information sharing practice of the factories with the suppliers, customers as well as internally within departments was not satisfactory. In this regard as argued by Lee and Whang (2000); and Lee (2002), information sharing is one of the keys that enable factories to achieve effective supply chain management and the basement for successful integration among the supply chain partners. However, if there is no sufficient information sharing between partners in a supply chain, it will result from poor coordination that will lead to many serious problems such as high inventory levels, inaccurate forecasts, low resource utilization, and high production costs. Thus, with respect to this, the factories in this study need to view their informationsharing practice as a strategic asset and ensure that it flows with minimum delay and distortion.

Table 7.4. Information Technology

\begin{tabular}{llccc} 
N/S & \multicolumn{1}{c}{ Items } & $\mathrm{N}$ & Mean & SD \\
1 & $\begin{array}{l}\text { There is a high level of linkage with major customer through information } \\
\text { technology }\end{array}$ & 59 & 2.881 & 1.145 \\
2 & $\begin{array}{l}\text { There is high level of information exchange with our major supplier using } \\
\text { information technology }\end{array}$ & 59 & 2.932 & 1.112 \\
3 & $\begin{array}{l}\text { There is up-to-date IT technologies throughout the supply chain management } \\
\text { of the factory }\end{array}$ & 59 & 2.847 & 1.156 \\
4 & $\begin{array}{l}\text { There is adequate IT system throughout the supply chain management of the } \\
\text { factory }\end{array}$ & 59 & 3.050 & 1.135 \\
5 & $\begin{array}{l}\text { The level of IT based production process is effectively practice } \\
\text { All Items }\end{array}$ & 59.220 & 0.983 \\
& 59 & 2.986 & 1.106
\end{tabular}

Source: researcher's survey

Nowadays companies spend large amount of money for redesigning internal organizational and technical processes, changing traditional product distribution channels and customer service procedures to achieve ITenabled supply chain (Humphreys et. al, 2001) Information and communication technology (ICT) is an important enabler of efficient supply chain integration, and many ICT applications have recently gained popularity. This is due to their ability to facilitate, coordinate, and integrate the flow of information across the supply chain. ICT is an enabler for helping supply chain members to establish partnerships for better performance (Jharkharia \& Shankar, 2006). In relation to this, five items were used to measure IT application of the case factories as listed in table 7.4. Accordingly, the data in the table revealed, out of five items developed to see the extent of IT application four of them scored very poor practices with below 2 mean scores. Particularly, concerning the up-todatedness of IT application throughout the supply chain management of the factories and the level of effective 
implementation of IT-based production process identified the lowest with a mean value of $2.847(\mathrm{SD}=0.774)$ and $1.54(\mathrm{SD}=1.156)$ respectively. Moreover, the availability of adequate IT systems throughout the supply chain management of the factory and the level of information exchange with the major supplier using information technology also scored the lowest practiced in the factories with mean $3.050(\mathrm{SD}=1.135)$ and $\mathrm{M}=2.932(\mathrm{SD}=1.112)$ correspondingly. However, the level of linkage with major customers through information technology in the factories was practiced better than the remaining items of the table resulting in a mean value of $2.881(\mathrm{SD}=1.145)$. Generally, the overall mean value of all items of the SCM practice in terms of information technology $(\mathrm{M}=2.986$ $\mathrm{SD}=1.106)$ was interpreted as a very poor application of information technology in the wheat flour factories under study. Furthermore, test results showed a statistical absence of significant differences at 0.05 levels of significances among the respondents' responses to the items listed in the table.

Table 7.5 Summary of Supply Chain Management Practices

$\begin{array}{llccr}\text { N/S } & \text { ITEM } & \mathrm{N} & \text { MEAN } & \text { SD } \\ 1 & \text { Suppliers and Customer relationship } & 59 & 3.014 & 0.823 \\ 2 & \text { Internal operation practices } & 59 & 3.074 & 1.067 \\ 3 & \text { Information Sharing practices } & 59 & 2.986 & 1.106 \\ 4 & \text { Information Technology } & 59 & 2.612 & 0.813 \\ & \text { All Items } & 59 & 2.921 & 0.952\end{array}$

Source: Researcher's Survey

The results obtained from respondents concerning the basic SCM practices in the wheat flour producing factories of the study area where summarized and illustrated in table 7.5. According to the results shown in the table the overall mean score $2.921(\mathrm{SD}=0.952)$ indicated the practices of supply chain management in the factories was found below moderate level. The maximum mean score was $3.074(\mathrm{SD}=1.067)$ concerning internal operation practices of the factories; and the minimum mean 2.612 ( $\mathrm{SD}=0.813$ ) was regarding application of information technology in the practice of SCM. This indicate the factories are relatively better in internal operation practices which was resulted above moderate level than the practice of others SCM practices included in this study. On the contrary utilizing information technology, in order to facilitate the practice of SCM effectiveness in the flour factories not obtained sufficient attention in the factories and poorly practiced. Besides, the data illustrated in table 7.5 also shows the practice of the factories regarding their relationship with suppliers and customers $(\mathrm{M}=3.014, \mathrm{SD}=0.823)$ and information sharing practices both internally and externally $(\mathrm{M}=2.986, \mathrm{SD}=1.106)$ identified as they were practiced almost at moderate level in the case factories.

According to Lambert, (2000) SCM offers the opportunity to capture the full potential of intra and intercompany integration and management. Therefore, SCM deals with business process excellence and represents a new way of managing the business and relationships with other members of the supply chain. Lambert (2000) added that if executives understand the supply chain management processes and how they should be implemented, they will be able to create more integrated supply chains which will lead to higher revenues and increased profitability for all member firms.

In general, the summary of items related to supply chain management practices illustrated in the table, signified below satisfactory level of flour producing factories practices in the study area without statistically significant differences among the responses of respondents. This confirms the success and achievement of the SCM objectives in those flour factories were not effectively practiced.

\subsection{The Effect of SCM Practices on Operational Performances}

In this part, the data regarding the consequences of SCM practices on the operational performance of wheat flour factories were presented and analyzed using the results of descriptive statics and regression results calculated to respond the third basic research question of the study: What is the overall effect of supply chain management practices on the operation performances of the wheat flour factories in Adama city.

The supply chain is a key framework for understanding how a product moves from the supplier to the customer. The supply chain perspective in wheat flour factories provides an important means to understand the business-business relationships, mechanisms for increasing efficiency, and ways to enable the business to increase productivity and add value. Effective and efficient utilization of resources, product quality and development and good product delivery condition let the flour factories to boost their operational performance and increase customer satisfaction correspondingly (Day \& Lichtenstein, 2006). 
Table 7.6. The results of descriptive statics on Operational Performances of the factories $\mathrm{N} / \mathrm{S}$

1 Our company can quickly modify products to meet our major customer's $\mathrm{N} \quad$ Items $\mathrm{SD}$ requirements.

2 Our company can quickly respond to changes in market demand in terms of both volume and quality of the product

3 Our company benchmark it's production performance with leading companies in the sector

4 Our company pays attention for the reduction in wastage of resources

5 Our production processes focuses on more efficient works involving less fatigue to workers

6 Our company invest in more efficient equipment and technologies that facilitate automation

7 Our company aims at the maximum utilization of resources for yielding as many goods and services as possible,

8 Our company develops an attitude of mind

Source: researcher's survey

In this regard, the data in table 7.6 illustrate responses related to the operating performance of the flour producing factories under study. According to the data of the table, the overall operating performance of the factories was moderate resulting 3.00 mean score $(\mathrm{SD}=1.182)$. However, when the mean score of the items regarding operation management of the factories was compared the factories are relatively better in quickly modifying products to meet major customer's requirements $(\mathrm{M}=3.62, \mathrm{SD}=1.158)$; quickly responding to changes in market demand in terms of both volume and quality of the wheat flour $(\mathrm{M}=3.37, \mathrm{SD}=1.112)$ and benchmarking their performances with other wheat flour factories $(\mathrm{M}=3.44, \mathrm{SD}=1.355)$.

However, the factories were not efficient in facilitating automation by investing on more efficient equipment and technologies $(\mathrm{M}=2.49, \mathrm{SD}=1.179)$; focusing on more efficient works involving less fatigue to workers $(\mathrm{M}=2.94, \mathrm{SD}=1.076)$ and developing an attitude of mind to find better means of doing things right $(\mathrm{M}=2.59$, $\mathrm{SD}=1.146)$. Moreover, operation performance of the factories regarding maximum utilization of resource for yielding more wheat flour products in terms of both volume and quality was also found almost at a moderate level $(\mathrm{M}=3.37, \mathrm{SD}=1.112)$ However, the factories are better $(\mathrm{M}=3.42, \mathrm{SD}=1.220)$ in paying attention for the reduction in wastage of resources when compared with maximum utilization of available resources $(\mathrm{M}=2.18, \mathrm{SD}=1.210)$.

In general, the operation performance of the company was found above a moderate level in making effort to meet measure customer's requirements, responding to market demand and benchmarking with the leading similar factories. But they were weak in utilizing appropriate technologies that facilitate automation, focusing on more efficient production processes and developing an attitude of mind that enables doing things right; which are the most important elements for the better operational performance of the manufacturing sector.

\subsection{Correlation Analysis}

Under research Investigation we are expected to understand converts beyond the means and standard deviations of the dependent and independent variables, so we need to know how one variable is related to another which comes with the concept of correlation. 
Table 7.7. Correlation Matrix between SCM Practices and Operation Performance

\begin{tabular}{|c|c|c|c|c|c|c|}
\hline & & A & B & C & D & $E$ \\
\hline \multirow{3}{*}{$\begin{array}{l}\text { Suppliers and } \\
\text { relationship(A) }\end{array}$} & Pearson Correlation & 1 & .190 & $0.128^{*}$ & .079 & $.297^{*}$ \\
\hline & Sig. (2-tailed) & & .150 & .023 & .554 & .335 \\
\hline & $\mathrm{N}$ & 59 & 59 & 59 & 59 & 59 \\
\hline \multirow[t]{3}{*}{ Internal Integration (B) } & Pearson Correlation & & 1 & $.598^{* *}$ & $.397^{* *}$ & .128 \\
\hline & Sig. (2-tailed) & & & .000 & .002 & .332 \\
\hline & $\mathrm{N}$ & & 59 & 59 & 59 & 59 \\
\hline \multirow[t]{3}{*}{ Information Sharing (C) } & Pearson Correlation & & & 1 & $.365^{* *}$ & .014 \\
\hline & Sig. (2-tailed) & & & & .004 & .918 \\
\hline & $\mathrm{N}$ & & & 59 & 59 & 59 \\
\hline \multirow[t]{3}{*}{ IT Uses (D) } & Pearson Correlation & & & & 1 & .009 \\
\hline & Sig. (2-tailed) & & & & & .948 \\
\hline & $\mathrm{N}$ & & & & 59 & 59 \\
\hline \multirow[t]{3}{*}{ Operational performance(E) } & Pearson Correlation & & & & & 1 \\
\hline & Sig. (2-tailed) & & & & & \\
\hline & $\mathrm{N}$ & & & & & 59 \\
\hline
\end{tabular}

Source: Own Survey result,2019

*.Correlation is significant at the 0.05 level(2-tailed)

**.Correlation is significant at the 0.01 level (2-tailed).

The correlation coefficient calculated between SCM practices and operational performances of wheat flour producing factories were illustrated in table 7.7. As it has been indicated in the table, the relationship between operational performance and all items of SCM practices were positive. This means the practices SCM and operational performance have a direct relationship in wheat flour factories. That is, as the factories increase SCM practices; their operational performance will also increase. Similarly, regarding the relationship of Operational Performance with 'Internal Operation' $(\mathrm{r}=0.128, \mathrm{P}<0.01)$ and that of 'Supplier and Customer relationship' $\left(\mathrm{r}=0.297^{*}, \mathrm{P}<0.01\right)$ the results of the table showed a higher degree of correlation.

This indicates the internal operation of the factories and their relationship with suppliers and customers was positive and strongly correlated with operational performances of them. So, the enhancement of Internal Operation of the factories and their relationship with suppliers and customers will result in a very significant incensement of operation performances in the flour factories.

Nevertheless, a moderate degree of correlation was identified between 'operational performance' and 'Information sharing' practices of the factories $(\mathrm{r}=0.014, \mathrm{P}<0.01)$. Regarding the relationship between the application of Information Technology and the operational performance of the factories; the results of the table showed weakly or a lower degree of correlation $(\mathrm{r}=0.009, \mathrm{P}<0.05)$ at a $95 \%$ level of confidences. This implies that the application of IT in the operational management of the flour factories was weak and insignificant.

\subsection{Multiple Regression Analysis}

Multiple linear regression analysis is a method that uses more than one independent variable to explain variance in a dependent variable.

\subsubsection{Regression between Supply Chain Management and Operation Performance}

Model Summary ${ }^{\mathrm{b}}$

\begin{tabular}{|c|c|c|c|c|}
\hline Model & $\mathrm{R}$ & R Square & Adjusted R Square & Std. Error of the Estimate \\
\hline 59 & 0.751 & .564 & .540 & .37591 \\
\hline
\end{tabular}

a. Predictors: (Constant), Information Sharing, Suppliers and customers relationship, Internal Integration

b. Dependent Variable: Operational performance

The multiple correlation coefficients (r), with a value of 0.751 represent the correlation ratio indicating the existence of a strong link between operational performance of the factories and their SCM practices. The determination coefficient-R Square has the value 0.564 and expresses that $56.40 \%$ of the variation of factories operational performance can be explained by the practices of SCM variables taken into consideration. The adjusted correlation ratio also shows that 0.540 of the total variation is due to the regression line, given the number of degrees of freedom. 
ANOVA

Model

$\begin{array}{lccccc} & \text { Sum of Squares } & \text { Df } & \begin{array}{l}\text { Mean } \\ \text { Square }\end{array} & \text { F } & \text { Sig. } \\ \text { Regression } & 10.045 & 3 & 3.348 & 23.695 * * & 0.000 \\ \text { Residual } & 7.772 & 55 & .141 & & \\ \text { Total } & 17.817 & 58 & & \end{array}$

a. Predictors: (Constant), Information Sharing, Suppliers and customers relationship, Internal Integration

b. Dependent Variable: Operational performance

Test $\mathrm{F}$ shows the role of the independent variables to explain the evolution of the dependent variable. The value of test $F(23.695)$ and of the materiality $(0.000<0.05)$ shows that the regression model is valid and can be used to analyze the dependence between the variables.

Regression

\begin{tabular}{|c|c|c|c|c|c|}
\hline \multirow[b]{2}{*}{ Model } & \multicolumn{2}{|c|}{$\begin{array}{l}\text { Unstandardized } \\
\text { Coefficients }\end{array}$} & \multirow{2}{*}{\begin{tabular}{|l}
$\begin{array}{l}\text { Standardized } \\
\text { Coefficients }\end{array}$ \\
Beta \\
\end{tabular}} & \multirow[b]{2}{*}{$\mathrm{t}$} & \multirow[b]{2}{*}{ Sig. } \\
\hline & B & $\begin{array}{l}\text { Std. } \\
\text { Error }\end{array}$ & & & \\
\hline (Constant)(Constant) & .611 & .295 & & $2.069^{*}$ & .043 \\
\hline $\begin{array}{l}\text { Suppliers and customers } \\
\text { relationship }\end{array}$ & .336 & .101 & .344 & $3.314 * *$ & .002 \\
\hline Internal Integration & .285 & .085 & .380 & $3.375 * *$ & .001 \\
\hline Information Sharing & .156 & .071 & .220 & $2.191 *$ & .033 \\
\hline
\end{tabular}

Source: Own Survey result, 2019

a. Dependent Variable: Operational performance

b. Dependent Variable: Operational performance

The constant term with the value of 0.611 is also the point of intersection of the regression. Since the statistic $\mathrm{t}=2.069$ and $\mathrm{P}$ - value $=0.000<0.05$. The coefficient for the suppliers and customer relationship, with the value of 0.336 , is positive and indicates the existence of a direct link between operational performance and suppliers and customer relationship of the factories, and the $\mathrm{P}$-value $=0.002<0.05$. This indicates a unit increase in suppliers and customer relationships of the factories will result in an increase of operation performances by 0.336 points.

The coefficient corresponding to the internal integration variable, with the value of 0.285 , is positive and indicates the existence of a direct link between operational performance and internal integration of the factories so that a unit increase of internal integration will determine the operational performance to increase with 0.285 points. Since $\mathrm{P}$ - value $=0.001<0.05$.

Moreover, the coefficient corresponding to the information sharing variable, with the value of 0.156 , is positive and indicates the existence of a direct link between information sharing and operational performance; so that a unit increases of information sharing will determine operational performance to increase with 0.156 points. Thus, the following regression model results from the analysis of the coefficients:

$\varnothing$ Operational performance $=$ Constant term + Supplier and Customer Relationship + Information Sharing + Internal Integration + Residual Value

$\mathrm{OPP}=0.611+0.336 \mathrm{SCR}+0.285 \mathrm{IIN}+0.156 \mathrm{ISH}+\varepsilon i$

Where:

$\mathrm{OPP}=$ Operational Performance

$\mathrm{SCR}=$ Supplier and Customer Relationship

$\mathrm{ISH}=$ Information Sharing

$\mathrm{IIN}=$ Internal integration

$\varepsilon i=$ residual value

The results presented in the table above show that all the variables: operation performance is positively influenced by three variables taken under the SCM practices. However, one variable included under SCM practices (Application of Information Technology) was not statistically significant to influence the operation performance of wheat flour factories currently operating in Adama city.

\section{SUMMARY, CONCLUSIONS, AND RECOMMENDATIONS}

\subsection{Summary of the Findings}

The major purpose of this study was to investigate the Effect of Supply Chain Management Practices on Operational Performance in Selected Wheat Flour Factories in Adama City. In order to achieve this objective attempt was made to answer basic research questions.

In doing so the data were collected using questioner and interviews. Initially, the questioners were distributed 
to 68 sample respondents selected from the 4 factories. Out of 68 questionnaires distributed to the respondents, 59 $(86.8 \%)$ were correctly filled and returned. In addition, interview responses obtained from general managers of the factories were also considered. Analyses and interpretations were made using the data illustrated in tables. Furthermore, the qualitative data was analyzed and narrated accordingly. In addition, discussions on the findings of the study were made by comparing the results with the literature review and empirical evidence. Thus, based on the analysis made in accordance with the study objectives, major findings were summarized as follows.

\subsubsection{The Practice of SCM}

As was described in the literature review, the strength partnership a company had with a supplier can influence the strategic and operational capabilities of manufacturing firms in order to achieve significant ongoing benefits (Li et. al, 2006). However, the overall mean score of 2.63 results of the firms' relationship with the suppliers indicated the practice of the factories regarded the relationship with suppliers was weak.

The variables tested in this regard including long term stable strategic partnership with suppliers, the trends of problem-solving jointly with suppliers, sharing of suppliers' production schedule and improvement to better meet the needs of the firms were given little or no attention by flour factories firms. This may affect the effectiveness of SCM of the factories and their relationship with the suppliers for future business strategy.

The overall mean result $(\mathrm{M}=3.014)$ for all items of suppliers and customers relationship of the factories indicated a moderate level of factory practices concerning their relationship with suppliers and customers.

The result of this study regarding the internal operation practice of wheat flour factories resulted above a moderate level of respondents' responses $(\mathrm{M}=3.074)$.In this regards, eight variables were used in order to see the extent of the internal integration of the case factories; that is, in terms of real-time integration, joint decision making, employees' perception of company's goals, the extent of continuous and instantaneous product and service improvement and consultation and discussion practices during the decision making internally and the existence of conflict between departments related to the practice of supply chain management in the factory.

From all the practices the periodic interdepartmental meeting among internal departments scores below average result and confirmed that they had no trend of discussing and consulting the internal departments on a timely base. But workplace meeting has benefits such as; better decisions, broader buy-in and consensus, a better understanding of complex problems and issues, more complete resolution of conflicts, and more thorough followup and follow-through. On the other hand, all the remained internal practices scored moderate results. Therefore it can be concluded that the wheat flour factories had moderate internal integration within the factory.

As described in the literature review, sharing important information between supply chain partners of wheat flour firms timely is an essential element to compete in highly competitive business environments.

In this study, regarding the information-sharing practices, the variables that can indicate the extent of firms' information sharing practices, like sales forecast and new product development with customers and suppliers, sharing standardized and customized information internally, maintaining integrated database between departments and effectively sharing of production information internally were incorporated. Accordingly, all information sharing variables mean values were below found at 3.00 mean score except effective sharing of product information between departments internally that scored 3.18. This means information sharing practices in the supply chain of wheat flour firms were weak with suppliers as well as suppliers. The overall mean score regarding the information-sharing practice of the case factories was found below moderate level $\mathrm{M}=2.61$; indicating insufficient information-sharing practice with its suppliers, customers and internally within the organization.

At the least side of SCM practices, the applications of ICT in wheat flour factories score an overall mean value of 2.847 which was interpreted as a poor application of information technology. The items used in this study to evaluate the application of ICT in the wheat flour factories were; linkage with major suppliers as well as with customers through ICT, the up-to-date of ICT application through the SCM, the availability of IT throughout the SCM of the factory and the level of IT-based production process were responded with a very low level of respondents responses. The mean result of all these practices confirmed that the wheat flour factories were very weak in the application of ICT in the manufacturing process.

\subsubsection{The Effects of SCM practice on operational performance}

Concerning the operational performances of the factories, the overall results of the respondents' responses were found at a moderate level $(\mathrm{M}=3.00)$; particularly, in making effort to meet measure customer's requirements, responding to market demand and benchmarking with the leading similar factories. But the factories were weak in utilizing appropriate technology that facilitates automation, focusing on more efficient production processes and developing an attitude of mind that enable doing thing right. Those are the most important elements for better operational performances.

\subsection{Conclusions}

Efficient supply chain management practices have a greater impact on organizational performance when properly identified and implemented. The central objective of the study was to assess the level of practical implementation of SCM practices and to analyze the effects of SCM practices on operational performance in wheat flour producing 
factories in Adama city. For this purpose, four key dimensions of supply chain management practices as well as operational performance indicators were used as research variables.

The results of the study show that the implementation of modern SCM practices is weak in wheat flour producing factories in Adama with the exception of some moderate results on supplier and customer relationships and internal integration practices which were performed better. The information sharing and the application of ICT practice resulted in relatively weaker performance but all the variables except ICT practice in the SCM practices had a positive influence on operational performance on the wheat flour producing factories. ICT practice had no significant effect on the operational performance of the case factories.

It can, therefore, be concluded that the sector is doing business as usual and no attention was given to modern SCM theories and practices in the sector yet. However, the existing literature advocates that the implementation of SCM practices can considerably improve the operational performance of a given organization.

\subsection{Recommendations}

From the research findings, we can conclude that wheat flour factories have been operating for a long time. However, modern supply chain management theories and practices are not given the attention of business managers. Still, the wheat flour sub-sector is doing business in the traditional way of customer-supplier relationships. Their information sharing practices and internal operation flexibility to address customer's demand change are also weak.

The sector relatively gives more attention to internal coordination rather than collaboration with external supply chain partners mainly with suppliers. In general, supply chain management practice in wheat flour producing factories is not used as a weapon to enhance their operational performance. Therefore, the following suggestions were forwarded in order to improve the Supply Chain Management of the case wheat flour factories.

It is noticeably explained that internal integration is vital in increasing the potential of the companies to get external integration. The flour factories are suggested to integrate the internal operational units, so as to bring about flexible, responsive and efficient production. This can be done by networking the functional units of the organization with appropriate IT and integrated information systems. Breaking functional silos to encourage coordination and interdependent work design accompanied by the agile workforce and multipurpose machinery to improve flexibility and responsiveness to market and customers' requirements are also required.

The current information technology practice of the case flour factories was poor and affects effective communication and integration of data within the company. The case Company should improve and invest in IT facilities to enhance information sharing both internally and externally. In addition, firms should focus on maintaining long term partnering relationship with customers and suppliers and they should involve on in joint planning and problem-solving activities as well as organizing continuous improvement programs on different issues to reduce some challenges of the sector like inferior product quality, extended delivery time and low competitive prices of the products. Establishing long term contract agreement with dependable suppliers/customers could also reduce time and cost for supply chain members. More importantly, the case factories are suggested to improve their relationship with suppliers from simply buy-sale relationship to a modern supply chain relationship through establishing strategic or long term relationship, contract, and continuous information sharing in order to minimize supply uncertainty which resulted in demand and supply unmatched and dissatisfaction of customers of the case company. Because this could help the case factories to obtain the inputs at the right time and quantity from these suppliers and provide the required quantity by the customers when they need it.

Another important issue that is suggested to the case flour factories marketing department is improving the relationship with customers through a continuous information sharing, follow- up to them and get feedback, monitoring customers' perceptions towards service of the company, improving its compliant management through conducting market research for better responsiveness.

\section{Suggestions for Future Research}

Finally, since in this study the researcher had given attention only about operational performances of the case factories, other performance measures such as; finance and production performances are not included. Therefore, it is recommended for future research to consider other performance measures of those factories.

\section{Reference}

1. Admaw, Anley (2010). Impact of supply chain management practices on competitive positioning of Ethiopian Textile firms. Graduate School of Business Leadership University of South Africa

2. Assefa, Balda (2011). Model The study on supply chain management practices a case study of Kality Food Share Company. Master's thesis; Addis Ababa University, Addis Ababa, Ethiopia.

3. BeteGeorgise, Fasika, Klause-Dieter, Thoben and Seifert, Marcus (2014).Integrating Developing Country Manufacturing Industries into Global Supply Chain. Journal of Industrial Engineering and Management, 7(1): 174-193. 


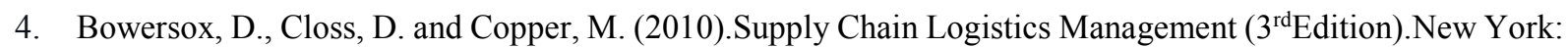
McGraw Hill, International Edition.

5. Cheung, M. S., Myers, M. B. \&Mentzer, J. T. (2010). Does relationship learning lead to relationship value? A cross-national supply chain investigation. Journal of operations management, 689(1): 1-16

6. Chow, W.S., C.N. Madu, C. H. Kuei, M.H. Lu, C. Lin, H. Tseng. (2008). Supply chain management in the US and Taiwan, an empirical study. International Journal of management science, 36, 665 - 679

7. Cohen, Louis; Manion, Lawrence; and Morrison, Keith (2007).Research Method (6 $6^{\text {th }}$ Edition).

8. Daniel, Atnafu (2013). The Effect of Supply Chain Integration on Operational Performance and Associated Challenges: A Study on Chemical and Chemical Product Manufacturing Firms in Ethiopia. Master's Thesis; Bahir Dar University, Bahir Dar, Ethiopia. Study of Supply Chain Strategies. Journal of Operations Management, 19(2), 185-200.

9. Gunasekaran, A., Patel, C, and Mc Gaughey, R. (2004). A framework for supply chain performance measurement. Int. J. Prod. Econ, 87, 333-347

10. Habtamu, Werkneh (2010). Analysis of Technical Efficiency of the Ethiopian Agro Processing Industry: The Case of Biscuit and Pasta Processing Firms. Master's Thesis, Addis Ababa University, Addis Ababa, Ethiopia

11. Hailemickael Deres (2011). Supply Chain Performance of selected leather Footwear firms in Addis Ababa. Master's Thesis, Addis Ababa University, Addis Ababa, Ethiopia

12. Handifield, and Nichols (1999). Introduction to supply chain management. New Jersey: Prentice-Hal, Inc.

13. Lazarevic, P., Sohal, A., and Baihaqi, I. (2007). Supply chain management practices \& supply chain performance in the Australian Manufacturing Industries. In Monish university.

14. Naresh, Ram (2005). A modern approach to operations management. New Delhi: New Age International PLtd Stadtler, H, and Kilger, C. (2008).

15. Supply chain management and advanced planning: concepts, models, software, and case studies ( $\left.4^{\text {th }} \mathrm{Ed}\right)$. Berlin: Springer Stadtler, H. (2008).

16. Supply chain management - an overview. In Stadtler H, Kilger C (eds) Supply chain management and advanced planning: concepts, models, software, and case studies. Berlin: Springer Sutton, John \&Kellow, Nebil (2010).An Enterprise Map of Ethiopia. London: International Growth Center.

17. Thatte, (2007).Competitive advantage of a Firm Through Supply Chain Responsiveness and Supply Chain Management Practices. Published PhD Dissertation. University of Toledo.

18. UNIDO, (2009).Master Plan: A Strategic Plan for the Ethiopian Agro-processing Industry Products Industry. Addis Ababa: UNIDO

19. Wadhwa, S. and Saxena, A. (2007). Decision knowledge sharing: flexible supply chains in KM context Production Planning \& Control. TheManagementofOperations,5,436- 452

20. Wisner, J. and Tan, K. (2000). Supply chain management and its impact on purchasing. Journal of Supply Chain Management, 36 (4), 33-42

21. Zhang, Q., Vonderembse, M., and Lim, J. (2003).Manufacturing Flexibility: Defining and Analyzing Relationships among Competence, Capability and Customer Satisfaction. Journal of Operations Management, 21(2), 173-191 